\title{
International Laws on Money Laundering
}

\author{
Ahmad Aqeil Mohamad Al-Zaqibh
}

\begin{abstract}
The term "money laundering" was only applied to financial transactions related to organized crime in the past. But today the definition is expanded by government regulators, to include any financial transaction which produces assets of an illegal act, which may involve actions such as tax avoidance or false accounting. In a simple meaning, money laundering refers to illegal or dirty money is put through cycle of transactions or cleanse, so that it comes out the other end as legal or clean money. This paper discusses the international money laundering laws such as the Vienna Convention, FATF and the Palermo Convention as well as UAE legal system (Anti-Money Laundering Act). Based on these facts, the paper infers that money laundering is a serious problem in new era and the laws against money laundering are not completely effective because the biggest problem arise with regard to enforcement. Finally, this paper presents some recommendations that important in the fighting against Money Laundering.
\end{abstract}

Index Terms - Illegal activities, money laundering, organized crime and tax haven.

\section{INTRODUCTION}

The CNN had broadcasted in its news that he British-owned bank HSBC was investigated for involvement in the transfer of funds from Mexican drug cartels and sanctioned nations like Iran and on $10^{\text {th }}$ December 2012, the Europe's largest bank by market value had agreed pay the biggest penalty ever imposed on a bank which is an amount of $\$ 1.9$ billion to avoid a legal battle that could further savage its reputation and undermine confidence in the global banking system.

In September 2012 issue of Indian Times it was stated that Jharkand's former Chief Minister, Madu Kodha was charged for knowingly assisting and allegedly being a party in the process and activities connected with the proceeds of crime between February 2005 and September 2006 when he was mines minister and September 2005 and August 2008 during his chief ministerial tenure.

One of the famous case was mentioned the UN General Assembly on $8^{\text {th }}$ to $10^{\text {th }}$ June 1998 . It was about the money laundering offence committed by Franklin Jurado, a Harvard-educated Colombian economist, who pleaded guilty to a single count of money laundering in a New York federal court in April 1996 and was sentenced to seven and a half years in prison. Using the tools he learned at America's top university, he moved \$36 million in profits, from US cocaine sales for the late Colombian drug lord Jose Santacruz Londono, in and out of banks and companies in an effort to make the assets appear to be of legitimate origin. Money laundering is the problem of new era where it takes place at

Manuscript received October 13, 2012; revised December 20, 2012.

Ahmad Aqeil Mohamad Al-Zaqibh is with Salman Bin Abdulaziz University (e-mail: ahmadalzaqibah@yahoo.com). various countries around the globe.

It is a criminal act of transferring money that was derived from almost any criminal activity such as organized crime, white-collar offenses, and drug transactions into seemingly legitimate channels, in an attempt to disguise the origin of the funds. The International Monetary Fund (IMF) had defined the offence in its official website as a process by which the illicit source of assets obtained or generated by criminal activity is concealed to obscure the link between the funds and the original criminal activity.

A similar explanation was given by an intergovernmental body which is known as The Financial Action Task Force (FATF) that when a criminal activity generates substantial profits, the individual or group involved in criminal acts must find a way to control the funds without attracting attention of the underlying activity or the persons involved and criminals do this by disguising the sources, changing the form, or moving the funds to a place where there are less likely to attract attention.

Gilmore W.C who wrote "Dirty Money: The Evolution of Money Laundering Counter-Measures" (1999), had mentioned that the said offence only attracted interest in the 1980s, essentially, within a drug trafficking context. It was from an increasing awareness of the huge profits generated from this criminal activity and a concern at the massive drug abuse problem in western society which created the impetus for governments to act against the drug dealers creating legislation that would deprive them of then illicit gains.

But today its definition is often expanded by government regulators to encompass any financial transaction which generates an assets or a value as the result of an illegal act, which may involve actions such as tax evasion or false accounting and cyber terrorism where monies to carry out any terrorist activities been transferred safely. As a result, the illegal activity of money laundering is now recognized as potentially by individuals, small and large business, corrupt officials, members of organized crime or of cults, and even corrupt states or intelligence agencies, through a complex network of shell companies based in offshore tax haven.

The US Certified Anti-Money Laundering Specialist Association had expressed that money laundering being a threat to the good function of a financial system, it is critically important that Governments include all relevant voices in developing a national and international anti-money laundering program. The same concern by the international committees as it is very significant under the international documents. So, it has to be determined as to what problems are to be ruled by international law, and what problems are to be given over to national law in relation with money laundering. The role of international law in prescribing certain contents of law for the enforcement at domestic level is more for the unification and limited with recommendatory in nature unless it is an international treaty. 


\section{THE VIENNA CONVENTION}

As the international drug trafficking and the tremendous amounts of related money entering the bank system were very high, the United Nation, through the United Nations Drug Control Program (UNDCP) made the first move by an international agreement to combat drug trafficking and money laundering. This effort was seen in the adoption of the United Nations Convention against Illicit Traffic in Narcotic Drugs and psychotropic substances (Vienna Convention). The Convention came into force on November 11, 1990. The Vienna Convention, deals primarily with provisions to combat the illegal drug trades and related law enforcement issues. As of January 1, 2012, it was noticed at the UN Web Archive that there were 185 parties to the Convention. Although it does not use the term money laundering, the Convention defines the concept and call upon countries to criminalize the activity.

Article 1 of The Vienna Convention explains definitions. It is stated that "any property derived from or obtained, directly or in directly, through the Commission of an offence established in accordance with Article 3, paragraph 1 where property means asset of every kind, whether corporeal or incorporeal, movable or immovable, tangible or intangible, and legal documents or instruments evidencing little to, or interest in, such assets.

Under Article 4 Paragraph 1 of the Convention money laundering was explained as conversion or transfer of property, knowing that such property is derived from any offence or offences for the purpose of concealing or disguising the illicit origin of the property or of assisting any person who involved in the commission of such an offence or offences to evade the consequences of his action. Further it is stated that the concealment or disguise of the true nature, source, location, disposition, movement, rights with respect to, or ownership of property, knowing that such property is derived from an offence or offences established in accordance with sub-paragraph a) of this paragraph or from an act of participation in such an offence or offences.

The Convention defines proceeds with general definition because it strictly considers proceeds that derived from or obtained, directly or indirectly, from drug. This is limitation of it but it was established to fight against illicit traffic in narcotic drugs and psychotropic substances and at the same time fighting against money laundering, exclusively, precedes that derived from drug but introduce new phrase to legislation and lawmakers.

By its terms, the Vienna Convention limits predicate offences to drug trafficking offences. As a consequence, other crimes, such as, kidnapping, fraud and theft do not amount to money laundering offences under the said Convention. However, the international community has developed the view that the offences for money laundering should go well beyond drug trafficking.

Brown Alen had commented the same Convention in his book "Proceeds of Crime-Money Laundering, Confiscation and Forfeiture" (1996) that in general view, the Convention is accepted at international level as a fundamental document for fight against illicit traffic in narcotic drugs because it was first international Convention that include all proceeds from drug dealer as produce, transfer, sale, and prohibit money laundering derived from this activities, and make easily criminal international co-operation. With note into fundamental position this Convention, and with general considering other international documents that approved after the Vienna Convention, this is easily finding this point that all of these documents and Conventions have been inspired by the Vienna Convention.

Therefore European Commission, Financial Action Task Force (FATF) and other international instrument have expanded the Vienna Convention definition of predicate offences to include other serious crimes.

\section{FinANCIAL ACTION TASK ForCE (FATF)}

The FATF is an inter-governmental body whose purpose is to establish international standards and develop and promote policies, both at national and international levels, to combat money laundering (ML) and terrorist financing (TF). The FATF is a policy-making body which works to generate the necessary political will to bring about national legislative and regulatory reforms in these areas. The FATF also regularly examines methods, techniques and trends of money laundering and terrorist financing to ensure the continued relevance of its policies and standards. Since its inception, the FATF has operated under a finite life-span, requiring a specific decision of the Task Force to continue.

The first task of the FATF was to establish the international standard for combating money laundering. The FATF issued its first set of international anti-money laundering standards in 1990 the forty recommendations on money laundering. These recommendations were revised in 1996 so as to take into account changes in money laundering methods, techniques and trends. Report from FATF shows that in October 2001, as a response to the September 11 attacks in the United States, the FATF expanded its mandate and issued Eight Special Recommendations to deal with the issue of terrorist financing. The continued evolution of money laundering techniques led the FATF to undertake a through updating of the FATF standards in June 2003.

The US Government Accountability Office had published a report entitled 'International Financial Crime: Treasury's Roles and Responsibilities Relating to Selected Provisions of USA Patriot Act which was released on 12 June 2006. It has stated that in October 2004, the FATF published a Ninth Special Recommendation, making its overall standard as the $40+9$ Recommendations which is a strong framework for governments to develop their domestic efforts against money laundering and terrorist financing. The FATF standards have been endorsed directly by more than 170 jurisdictions around the world, as well as by the Boards of the International Monetary Fund (IMF) and the World Bank (WB).

In July 2005, the United Nations (UN) Security Council in its Resolution 1617 stated that it "strongly urges all Member States to implement the comprehensive international standards embodied in the Financial Action Task Force's (FATF) Forty Recommendations on Money Laundering and the FATF Nine Special Recommendations on Terrorist Financing." Consistent with its mandate, today's priority of the FATF is to ensure global action to combat money laundering and terrorist financing, and concrete implementation of its $40+9$ Recommendations throughout the world. Starting with its own members, the FATF monitors 
countries progress in implementing AML/CFT measures, reviews money laundering and terrorist financing techniques and counter-measures, and promotes the adoption and implementation of the 40+9 Recommendations globally.

In performing its work, the FATF collaborates closely with a number of partners, international and regional organizations that are involved in combating money laundering and terrorist financing. The FATF has developed strong partnership with these organizations in order to constitute a global network of organizations against money laundering and terrorist financing.

Money laundering methods and techniques change in response to developing counter-measures. Mascian daro, Donato had written a book on Global Financing Crime: Terrorism, Money Laundering and Offshore Centres (2004) where he had acknowledged that in recent years, the FATF has noted increasingly sophisticated combinations of techniques, such as the increased use of legal persons to disguise the true ownership and control of illegal proceeds, and an increased use of professionals to provide advice and assistance in laundering criminal funds. These factors, combined with the experience gained through the FATF's Non-Cooperative Countries and Territories process, and a number of national and international initiatives, led the FATF to review and revise the Forty Recommendations into a new comprehensive framework for combating money laundering and terrorist financing.

The FATF calls upon all countries to take the necessary step to bring their national systems for combating money laundering and terrorist financing into compliance with the new FATF Recommendations, and to effectively implement these measures. The review process for revising the Forty Recommendations was an extensive one; it is open to FATF members, non-members, observers, financial and other affected sectors and interested parties. This consultation process provided a wide range of input, all of which was considered in the review process.

The Recommendations therefore set minimum standards for action for countries to implement the detail according to their particular circumstances and constitutional frameworks. The Recommendations cover all measures that national systems should have in place within their criminal justice and regulatory systems; the preventive measures to be taken by financial institutions and certain other businesses and professions, and international co-operation.

In forty recommendations for fighting money laundering, FATF specifically incorporates the technical and legal definitions of money laundering set out in the Vienna and Palermo Conventions and lists 20 designed categories of offences that must be included as predicate offences for money laundering. In response to the growing concern about money laundering, the international community has acted on many fronts. The international response is, in large part, recognition of the fact that money laundering take advantage of high speed international transfer mechanisms, such as wire transfers, to accomplish their goals.

A key element in the fight against money laundering is the need for countries system to be monitored and evaluated, with respect to these international standards. The mutual evaluations connected by the FATF style regional bodies, as well as the assessments conducted by the IMF and World
Bank, are a vital mechanism for ensuring that the FATF Recommendations are effectively implemented by all countries.

\section{THE PALERMO CONVENTION}

In order to expand the effort to fight international organized crime, the UN adopted The International convention Against Transnational Organized Crime. This Convention contains a broad range of provisions to fight organized crime and commits countries that ratify this Convention to implement its provisions through passage of domestic laws. The Convention went into force on the $29^{\text {th }}$ of September 2003, having been signed by 147 countries and ratified by 82 countries. The Palermo Convention is important because its AML provisions adopt the same approach previously adopted by the Financial Action Task Force on Money Laundering (FATF) in its Forty Recommendations on Money Laundering.

The purpose of this Convention is to promote co-operation to prevent and combat transnational organized crime more effectively. The Convention includes 41 Articles and is most important international document that has special view to transnational organized crime. The Convention declare to parties that carry out their obligations under this Convention in a manner consistent with the principles of sovereign equality and territorial integrity of States and that of non-intervention in the domestic affair of other States.

The Convention discuss about money laundering in Article 6 and 7. This can be seen in Article 6 of Palermo Convention which defines money laundering as intentionally conversion or transfer of property knowing that such property is proceeds of crime, for the purpose of concealing or disguising the illicit origin of the property or of assisting any person who is involved in the commission of the predicate offence to evade the legal consequences of his actions. The concealment or disguise of the true nature, source, location, disposition, movement, rights with respect to, or ownership of, property, knowing that such property is the proceeds of crime; and subject to these constitutional principles and the basic concepts of its legal system. The acquisition, possession or use of property, knowing at the time of receipt, that such property is the proceeds of crime; by participation in, association or conspiracy to commit, attempts to commit and aiding, abetting, facilitating and counseling the commission of any at the offences established in accordance with this article. The Convention widely extent laundering offences in compare with Vienna Convention and include all of crime and not only drug crime. With consider Article 6 and 7 the Convention and compare with the Vienna Convention, this is easily finding progressive in this manner."

\section{MALAYSIAN MONEY LAUNDERING LAW}

In conformity with prevailing global aspirations and in order to fortify steps against terrorists and other illegal money laundering activities, the Malaysian Government introduced the Anti-Money Laundering Act, 2001 (AMLA). The Central Bank of Malaysia, Bank Negara Malaysia (BNM) has been appointed by the competent authority for the purpose of 
combating money laundering activities under the above act which came into force on 15 January 2002.

Under the Malaysian anti-money laundering law, money laundering is deemed, inter alia, as 'an act of a person who engages directly or indirectly in a transaction that involves proceeds of an unlawfully activity'. As defined under section 3 of the AMLA, it is any act which "acquires, receives, possesses, disguises, transfers, converts, exchanges or removes from or brings into Malaysia proceeds of any unlawfully activity". The bottom line is that for a transaction to be deemed money laundering, the money or asset concerned must, first of all, be the subject matter of an unlawful act. Thus, drug money or money derived from crime or criminal act is caught under the definition. Money gotten pursuant to kidnapping, robbery or extortion, for example, and transmitted in the aftermath is clearly laundered money. Even legal money can become illegal if moving it violates a country's foreign exchange controls or other financial regulations.

Malaysia is a growing regional financial center vulnerable to money laundering. Malaysia has developed an anti-money laundering and counterterrorist finance (AML/CFT) framework based on the country's Anti-Money Laundering and Anti-Terrorism Financing Act (AMLATFA). It has long porous land and sea borders and its strategic geographic position influence money laundering and terrorist finance in the region. Drug trafficking is the main source of illegal proceeds in Malaysia.

In February 2007, the Asia/Pacific Group on Money Laundering (APG) conducted its second Mutual Evaluation on Malaysia. The evaluation was based on all FATF recommendations. Malaysia's AML/CFT regime was found to be in compliance with the majority of the FATF's forty plus nine recommendations. The AMLAFTA provides for the establishment of a Financial Intelligence Unit (FIU) in Malaysia. The FIU was established in 2001 within the Central Bank. The FIU is tasked with receiving and analyzing information and sharing financial intelligence with the appropriate enforcement agencies for further investigation. The FIU cooperate with other relevant agencies to identify and investigate suspicious transactions. A comprehensive supervisory framework has been implemented to supervise financial institutions compliance with the AMLATFA and its subsidiary legislation and relevant guidelines.

Malaysia is active member of the Asia/Pacific Group (APG) on money laundering, a regional body designed along the lines of the Financial Action Task Force (FATF). In July 2006, Malaysia was selected as the co-chair of the APG Implementation Issues Working Group (IIWG), which is mandated to provide strategic support to members in implementing FATF Forty plus Nine Recommendations. As a co-chair, Malaysia has helped develop the Strategic Implementation planning framework, which aims to provide post-mutual evaluation implementation assistance to jurisdiction.

The Government of Malaysia should continue its involvement in AML/CFT matters on a regional, multilateral and international basis. Law enforcement and customs authorities should examine trade based money laundering and invoice manipulation and their relationship to underground finance and informal remittance systems. More effort should be made in identifying, investigating and prosecuting terror financing.

\section{UAE ANTI-MONEY LAUNDERING LAW}

UAE is an active member of Middle East and North Africa FATF and plays an important role in fighting against the money laundering activities in the region by having wide scope of offences. The principal laws fights against money laundering activities in UAE are Regulation No. 24/2000, issued by the Central Bank which contains provisions of an anti-money laundering infrastructure to banks and all financial institutions such as reporting any suspicious transactions. The main statute is the Anti Money laundering Act (Federal Law No. 4 of 2002), under Article 2 criminalizes money laundering with respect to specified predicate offences. The Government also has specific legislation to combat terrorism with money laundering with Federal Law No.1 of 2004 which combating terrorism offences, particularly Article 23 provides that any person who knows of a 'design' to commit any of the primary terrorist offences, which includes a terrorist finance offence, and does not report that fact to the relevant authority, commits an offence. There is also law to prevent any technology crime by having the Federal Law No.2 of 2006. There are other laws and regulations from Central Bank and Federal institutions that address particular Anti-Money Laundering issues either generally or in relation to particular sectors, e.g. the insurance industry, lawyers (the Lawyer Circular), and accountants (issued by the Ministry of Economy). For instance, the Lawyer Circular issued in June 2008, it is provided under Circular No.1 of 2008 that Lawyers within the UAE must verify client's identity, identity of parties to a transaction, the commercial objective of a transaction and the relevant 'owners and beneficiaries'.

\section{CONCLUSION}

Today money laundering is the one of major problem in phase of economy and security of governments. The international effort began with detection of drug trafficking as an international problem and could only be addressed effectively on a multilateral basis. As the types of crimes involving money laundering has been expanded, most of the countries have adopted The Vienna and Palermo conventions and also other efforts like FATF and MENAFATF into their domestic laws. As well as UAE with enact of AMLA is trying to prevent effect of money laundering. Generally, the fighting against money laundering needs special view and aware in society, therefore it is recommended that the legal literacy movement through governmental and non-governmental organization should be focused through multimedia system. A legal training should be formulated which would include knowledge regarding all laws regulations and rules of anti-money laundering. The laws against money laundering are not completely effective because the biggest problem arise with regard to enforcement.

\section{REFERENCES}

[1] B. Alen, Proceeds of crime-money laundering, confiscation and forfeiture, $1^{\text {st }}$ ed, Edinburgh Press, 1996 ch. 2 pp. 65-68. 
[2] W.C Gilmore, Dirty Money: The Evolution of Money Laundering Counter-Measures, $2^{\text {nd }}$ ed, Council of Europe Publishing, 1999 ch. 4. pp. $45-49$.

[3] M. Daro, Donato, Global Financing Crime: Terrorism, Money Laundering and Offshore Centre, Ashgate press, 2004. pp. 10-16.

[4] Accountants Today, Malaysian Institutes of Accountants January/February issue 2004.

[5] United Nations Convention against Illicit Traffic in Narcotic Drugs and Psychotropic Substances, Vienna Convention.

[6] International convention against Transnational Organized Crime, Palermo Convention.

[7] Regulations Concerning Procedures for Anti-Money Laundering, Central Bank of UAE (Regulation No. 24/2000).

[8] Federal Law No. 4/2002 regarding Criminalization of Money Laundering.

[9] Federal Law No. 1/2004 on Combating Terrorism Offences.

[10] UAE Lawyers Circular 1 of 2008.

[11] Anti Money Laundering Act 2001

[12] International Monetary Fund (IMF). The IMF and the Fight against Money Laundering and the Financing of Terrorism. [Online]. Available: http://www.imf.org/external/np/exr/facts/aml.htm.

[13] Official website of the Financial Action Task Force. [Online]. Available: http://www.fatf-gafi.org/pages/faq/moneylaundering/.

[14] Compliance Associates LLC. Certified Anti Money Laundering Specialist. [Online]. Available: http://amlbsa.com/faq.asp.

[15] United Nation (UN). United Nation on Drugs and Crime. [Online]. Available: http://web.archive.org/web/20071107135518/. http://www.unodc.org/unodc/en/treaty_adherence.html.

[16] Rohan Bedi. (February 2006). The Global Standard. [Online]. Available: http://www.rohanbedi.com/FATF40.pdf.

[17] U.S. Government Accountability Office (GAO). (June 12, 2006). International Financial Crime: Treasury's Roles and Responsibilities Relating to Selected Provisions of the USA PATRIOT Act. [Online]. Available: http://www.gao.gov/htext/d06483.html.

[18] Financial Action Task Force (FATF). (16 ${ }^{\text {th }}$ Feb 2012). International Standards on Combating Money Laundering and the Financing of Terrorism \& Proliferation - the FATF Recommendations. Paris. [Online].

Available: http://www.fatfgafi.org/topics/fatfrecommendations/documents/intern ationalstandardsoncombatingmoneylaunderingandthefinancingofterro rismproliferation-thefatfrecommendations.html.

[19] Official website of Middle East North Africa FATF. [Online]. Available: http://www.menafatf.org

[20] Official website of Bank Negara Malaysia. [Online]. Available: http://www.bnm.gov.my

[21] Official website of Overseas Assurance Corporation (Malaysia Berhad). [Online]. Available: http://www.oac.com.my/

Ahmad Aqeil Mohammad Al-Zaqibh was born in Irbid, Jordan on $25^{\text {th }}$ September 1980. He has obtained LLB (Hons) in Law from Yarmouk University, Jordan in 2002 and his Masters of Law from University Kebangsaan Malaysia (UKM) in 2005. He had completed his Doctoral Degree $(\mathrm{PhD})$ in International Laws at University Utara Malaysia (UUM) in 2010 .

In teaching field, he was a Law Lecturer at Multimedia University, Malaysia from May 2006 to August 2011 where he had given lectures on numerous subjects in English such as Business Law, Arbitration Law, Public and Private International Law. Currently he is working at Salman Bin Abdulaziz University, Saudi Arabia as an Assistant Professor for Business Law, Civil Law and Public International Law. Some of his published articles are Information Theft - A Real Threat: An overview 13th IBIMA Conference on Knowledge Management and Innovation in Advancing Economies in Marrakech, Morocco Credit Card Fraud and Malaysian Law Conference on Law and Technology Universiti Kebangsaan Malaysia Malaysia(2009) and Is Death Penalty the Ultimate Punishment? Aceh Development International Conference (ADIC) 2012 International Islamic University of Malaysia (IIUM). His areas of research are on International Laws and Commercial Laws.

Dr. Ahmad was an active member of Law Mooting Committee in Multimedia University (MMU) from 2007 till 2011. At Salman Bin Abdulaziz he is member of Quality Assurance Centre, responsible for Law Library in updating texts and journals and also member of Recruitment Team 